\title{
Study of 'Transition State' with Applied Potential [Mn - Sulfonamides - Cephalothin] System
}

\author{
M.S. Parihar and F. Khan* \\ Electrochemical Laboratory, Department of Chemistry, Dr. H.S. Gour University \\ Sagar-4700 003, M. P. India
}

Received 11 September 2007; accepted 13 May 2008

\begin{abstract}
Kinetic parameters and stability constants of [Mn - sulfonamides - cephalothin] system were reported at $\mathrm{pH}=7.30 \pm 0.01$ in $1.0 \mathrm{M} \mathrm{NaClO}_{4}$ at $25^{\circ} \mathrm{C}$. The sulfonamides were sulfadiazine, sulfisoxazole, sulfamethaxyzole, sulfamethazine, sulfathiazole, sulfacetamid e and sulfanilamide as primary ligands, and cephalothin as secondary ligand. Values of transfer coefficient $(\alpha)$ varied from $(0.41$ to 0.59$)$, showing that transition state behaves between oxidant and reductant response to applied potential and it adjusts itself in such a way that the transition state is located midway between dropping mercury electrode and solution interface. The rate constants $(\mathrm{k})$ varied from $3.61 \times 10^{-3} \mathrm{~cm} . \mathrm{sec}^{-1}$ to $9.93 \mathrm{x}$ $10^{-3} \mathrm{~cm}_{\text {sec. }}{ }^{-1}$, confirming that the electrode processes were quasi reversible. Small changes in potential not only affect the rate of the electrochemical reaction, but also strongly affect the rate constant. Values of stability constants $(\log \beta)$ varied from 1.75 to 9.13, showing that these drugs or their complexes could be used against Mn toxicity.
\end{abstract}

Keywords: electrode kinetics in [Mn - sulfonamides - cephalothin] system.

\section{Introduction}

Sulfonamide drugs were the first effective chemotherapeutic agents to be employed systematically for the prevention and cure of bacterial infections in man $[1,2]$. These drugs undergo metabolic alterations to a varying extent in the tissues, especially in the liver [2]. These drugs affect a broad spectrum of bacteria because of the wide distribution of the enzyme system which they disrupt [2]. Also, they are active against gram - positive cocci and gram negative bacilli [3] and some are possessing effective antifungal properties against the pathogenic yeast candida albicans $[4,5]$. On the other hand, cephalothin is a member of cephalosporin drugs which is used against bacterial infections and diseases

\footnotetext{
* Corresponding author. E-mail address: faridkhan58@yahoo.com
} 
therefore; the metal complexes of sulfonamide and cephalothin with Mn have great importance. The aim of the present investigation is to study the position of 'transition state' and its dependence on applied potential in [Mn - sulfonamides cephalothin] system and the kinetic parameters viz. transfer coefficient $(\alpha)$, degree of irreversibility $(\lambda)$, diffusion coefficient (D) and rate constant $(k)$ in these electrochemical reactions.

\section{Experimental}

All the chemicals were used as such without further purification and their solutions were prepared in deionized water (Millipore). Sodium salts of all the selected sulfur drugs (Sigma and Fluka) and cephalothin (Aldrich) were used. The $\mathrm{pH}$ of the analyte was measured on a $\mathrm{pH}$ meter (Elico - LI - 10) using glass and calomel electrodes and fixed at $7.30 \pm 0.01$ with dilute solutions of $\mathrm{HClO}_{4}$ or $\mathrm{NaOH}$ (both $\mathrm{BDH}$ ) as required. Polarograms were recorded on Polarographic Analyzer (Elico, Hyderabad Model CL - 362). The polarographic capillary was $5.0 \mathrm{~cm}$ in length with diameter $0.04 \mathrm{~mm}$ with characteristics $\mathrm{m}^{2 / 3} \mathrm{t}^{1 / 6}=2.04$ $\mathrm{mg}^{2 / 3} \mathrm{~s}^{-1 / 2}$. All the analytes were deaerated by nitrogen gas before recording the current-voltage graphs. Potassium dihydrogen phosphate-sodium hydroxide buffer was used to stabilize the $\mathrm{pH}$ of the analyte.

\section{Results and discussion}

$\mathrm{Mn}^{2+}$ gave a well defined two electron quasireversible wave at $\mathrm{pH}=7.20$ to 8.50 in the presence of $1.0 \mathrm{M} \mathrm{NaClO}_{4}$ at $25^{\circ} \mathrm{C}$ [6], but $\mathrm{pH}=7.30$ was selected on account of studying the complexes in human blood $\mathrm{pH}$. The waves of complexes were also quasireversible.

\section{[Mn-sulfonamide] system}

In this system, the concentrations of sulfonamide varied from $(0.5 \mathrm{mM}$ to 30.0 $\mathrm{mM}$ ) in each case. The concentration of metal, $\mathrm{NaClO}_{4}$ and Triton $\mathrm{X}-100$ were $0.5 \mathrm{mM}, 1.0 \mathrm{M}$ and $0.001 \%$, respectively. The $\mathrm{E}_{1 / 2}$ values became more negative on increasing the concentration of each sulfur drug to Mn showed complex formation. The Gellings [7] method was used to determine the $\mathrm{E}_{1 / 2}{ }^{\text {reversible }}$ values from $\mathrm{E}_{1 / 2}$ quasireversible values. Deford and Hume method [8] was used to determine the 1:1, 1:2 and 1:3 complexes with selected sulfur drugs. The values of stability constants were given in (Table 1).

\section{[Mn-sulfonamides-cephalothin] system}

This system was studied at $\mathrm{pH}=7.30 \pm 0.01$ at $\mu=1.0 \mathrm{M} \mathrm{NaClO}_{4}$ in presence of $0.001 \%$ Triton $\mathrm{X}-100$ used as suppressor at $25{ }^{\circ} \mathrm{C}$. The concentration of sulfonamide varied from $(0.5 \mathrm{mM}$ to $30.0 \mathrm{mM})$ at $0.025 \mathrm{M}$ to $0.050 \mathrm{M}$ of cephalothin. The half wave potential increased with the addition of cephalothin to the binary system [Mn - sulfonamide] showing ternary complex formation. 
Table 1. Stability constants values of $\left[\mathrm{Mn}\right.$ - sulfonamides - cephalothin] system, $\left[\mathrm{Mn}^{2+}\right]=0.50$ $\mathrm{mM}, \mu=1.0 \mathrm{M} \mathrm{NaClO}_{4}, \mathrm{pH}=7.30 \pm 0.01$, Temperature $=25^{\circ} \mathrm{C}$.

\begin{tabular}{|c|c|c|c|c|c|c|c|c|}
\hline Ligands & $\log \beta_{01}$ & $\log \beta_{02}$ & $\log \beta_{10}$ & $\log \beta_{20}$ & $\log \beta_{30}$ & $\log \beta_{11}$ & $\log \beta_{12}$ & $\log \beta_{21}$ \\
\hline sulfadiazine & - & - & 2.80 & 5.00 & 7.20 & 3.51 & 5.30 & 7.75 \\
\hline sulfisoxazole & - & - & 3.25 & 5.10 & 7.35 & 3.66 & 5.45 & 7.86 \\
\hline sulfamethaxyzole & - & - & 4.10 & - & 8.35 & 4.30 & 6.18 & 8.46 \\
\hline sulfamethazine & - & - & 4.15 & 7.20 & 8.40 & 4.32 & 7.35 & 8.60 \\
\hline sulfathiazole & - & - & 4.36 & 7.40 & 8.55 & 4.57 & 7.57 & 8.76 \\
\hline sulfacetamide & - & - & 4.51 & 7.61 & 8.75 & - & 7.80 & 8.90 \\
\hline sulfanilamide & - & - & - & 7.80 & 9.02 & 5.01 & 8.00 & 9.13 \\
\hline cephalothin & 1.75 & 2.65 & - & - & - & - & - & - \\
\hline
\end{tabular}

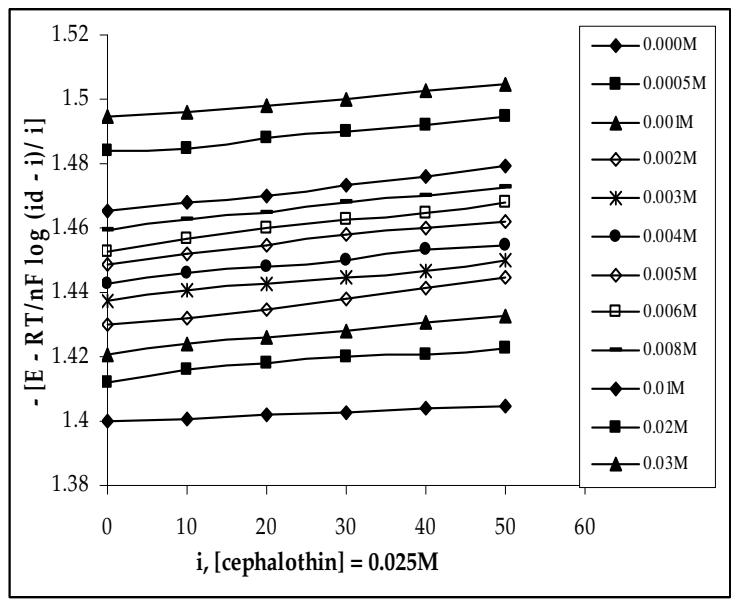

Figure 1. Plots between - [E-RT/nF log $\left.\left(\mathrm{i}_{\mathrm{d}} \mathrm{i}\right) / \mathrm{i}\right]$ vs. i for [Mn - sulfadiazine - cephalothin] system.

Gellings method was used to determine the $\mathrm{E}_{1 / 2}{ }^{\text {reversible }}$ values from $\mathrm{E}_{1 / 2}$ quasireversible values of complexes. Plots between $\left(\mathrm{E}-\mathrm{RT} / \mathrm{nF} \log \left(\mathrm{i}_{\mathrm{d}} \mathrm{i}\right) / \mathrm{i}\right)$ vs. $\mathrm{i}$ for $[\mathrm{Zn}-$ sulfadiazine - cephalothin] system at $[0.025 \mathrm{M}]$ cephalothin are given in Fig. 1. The stability constants of ternary complexes were determined by Schaap and McMaster method [9] which confirmed the formation of 1:1:1, 1:1:2 and 1:2:1 metal ligands complexes. To determine the values of $\beta_{11}$ and $\beta_{12}$, the study was carried out at $0.025 \mathrm{M}$ and $0.05 \mathrm{M}$ of [cephalothin]. The values of stability constants of complexes are given in Table 1 . The data and plots between $F_{\mathrm{ij}}[\mathrm{X}, \mathrm{Y}]$ vs. [X] for [Mn - sulfadiazine - cephalothin] system \{where $\mathrm{X}$ and $\mathrm{Y}$ are sulfonamide and cephalothin and $\mathrm{i}$ and $\mathrm{j}$ are the stoichiometric numbers for primary and secondary ligands, respectively are given in Table 2 and Fig. 2, respectively. The current-voltage curves for [ $\mathrm{Mn}$ - sulfadiazine - cephalothin] are given in Fig. 3. 
Table 2. Polarographic characteristics and $\mathrm{F}_{\mathrm{ij}}[\mathrm{X}, \mathrm{Y}]$ values of $[\mathrm{Mn}$ - sulfadiazine cephalothin] system, $\left[\mathrm{Mn}^{2+}\right]=0.50 \mathrm{mM}, \mu=1.0 \mathrm{M} \mathrm{NaClO}, \mathrm{pH}=7.30 \pm 0.01$, Temperature $=25^{\circ} \mathrm{C}$.

\begin{tabular}{|c|c|c|c|c|c|c|}
\hline \multicolumn{7}{|c|}{$[$ Cephalothin $]=0.025 \mathrm{M}$} \\
\hline $\begin{array}{c}{[\text { Sulfadiazine }]} \\
\times 10^{3} \mathrm{M}\end{array}$ & $\begin{array}{c}\mathrm{E}_{1 / 2}{ }^{\mathrm{r}} \\
-\mathrm{V} \text { vs. SCE }\end{array}$ & $\log \mathrm{I}_{\mathrm{m}} / \mathrm{I}_{\mathrm{c}}$ & $\mathrm{F}_{00}[\mathrm{X}, \mathrm{Y}]$ & $\begin{array}{c}\mathrm{F}_{10}[\mathrm{X}, \mathrm{Y}] \\
\times 10^{3}\end{array}$ & $\begin{array}{c}\mathrm{F}_{20}[\mathrm{X}, \mathrm{Y}] \\
\times 10^{5}\end{array}$ & $\begin{array}{c}\mathrm{F}_{30}[\mathrm{X}, \mathrm{Y}] \\
\times 10^{6}\end{array}$ \\
\hline 0.00 & 1.40 & - & - & - & - & - \\
\hline 0.50 & 1.42 & 0.0074 & 3.48 & 1.59 & 15.08 & 15.85 \\
\hline 1.00 & 1.42 & 0.0074 & 5.03 & 2.35 & 15.15 & 15.85 \\
\hline 2.00 & 1.43 & 0.0149 & 10.48 & 3.90 & 15.31 & 15.86 \\
\hline 3.00 & 1.44 & 0.0149 & 19.12 & 5.47 & 15.48 & 15.84 \\
\hline 4.00 & 1.44 & 0.0227 & 31.04 & 7.09 & 15.63 & 15.80 \\
\hline 5.00 & 1.45 & 0.0227 & 46.35 & 8.73 & 15.79 & 15.85 \\
\hline 6.00 & 1.45 & 0.0305 & 65.12 & 10.41 & 15.95 & 15.83 \\
\hline 8.00 & 1.46 & 0.0385 & 113.46 & 13.84 & 16.26 & 15.79 \\
\hline 10.00 & 1.47 & 0.0385 & 176.90 & 17.42 & 16.59 & 15.85 \\
\hline 20.00 & 1.48 & 0.0385 & 746.25 & 37.18 & 18.17 & 15.86 \\
\hline 30.00 & 1.49 & 0.0466 & 1805.73 & 60.10 & 19.76 & 15.85 \\
\hline
\end{tabular}

\section{Comparison of stability of the binary and ternary complexes}

Values of mixing constant $\left(\log \mathrm{K}_{\mathrm{m}}\right)$, which compare the stability of binary to the ternary complexes, can be given by the following equation [9]

$$
\log \mathrm{K}_{\mathrm{m}}=\log \beta_{11}-1 / 2\left[\log \beta_{20}+\log \beta_{02}\right]
$$

The values of $\log \mathrm{K}_{\mathrm{m}}$ were $(-0.315,-0.215,-0.605,-0.455$ and -0.215$)$ for [Mn sulfadiazine - cephalothin], [Mn - sulfisoxazole - cephalothin], [Mn sulfamethazine - cephalothin], [Mn - sulfathiazole - cephalothin] and [Mn sulfanilamide - cephalothin] systems, respectively. The negative values showed that binary complexes are more stable than their ternary complexes.

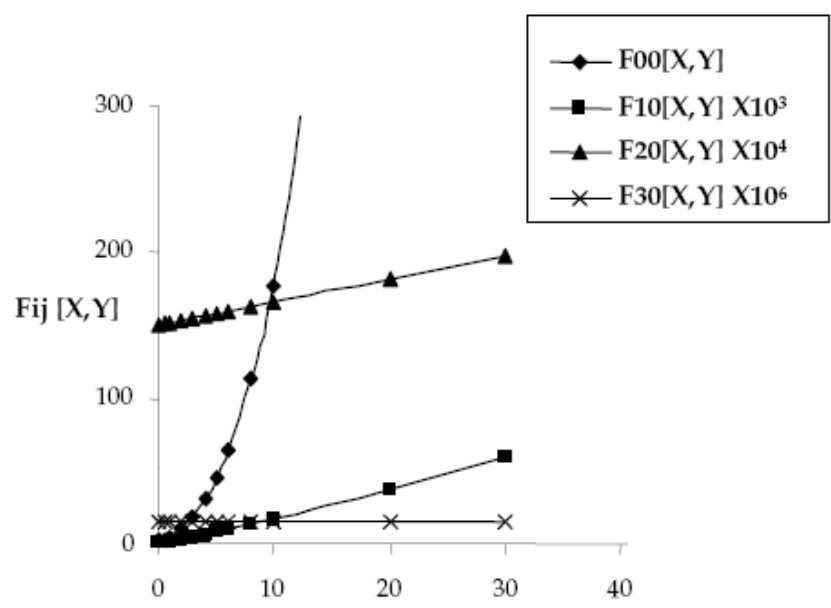

Figure 2. Plots between $\mathrm{F}_{\mathrm{ij}}[\mathrm{X}, \mathrm{Y}]$ values against $[\mathrm{X}]$ for $[\mathrm{Mn}$ - sulfadiazine -cephalothin] system (where $\mathrm{i}$ and $\mathrm{j}$ are the stoichiometric numbers for sulfadiazine and cephalothin, respectively). 

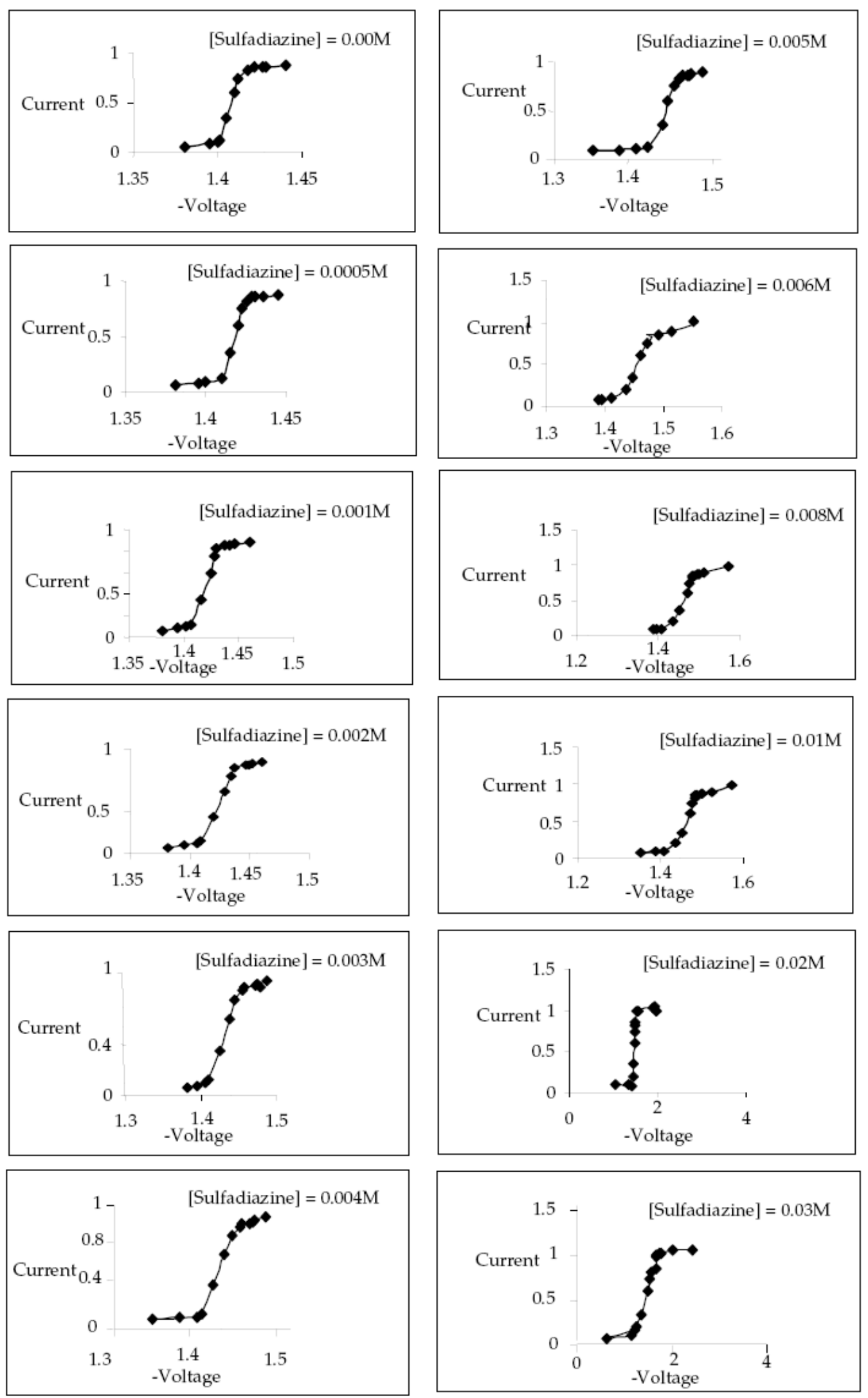

Figure 3. Polarograms of [Mn - sulfadiazine - cephalothin] system, [cephalothin] $=0.025 \mathrm{M}$. 
In case of sulfamethaxyzole and sulfacetamide, 1:2 and 1:1:1 complexes were not formed therefore; the values of $\log \mathrm{K}_{\mathrm{m}}$ were not reported for these systems. It is clear from the values of stability constants of these complexes that the sulfadiazine formed the complexes of minimum stability, which is due to the fact that its complexes showed the lowest values of $\mathrm{E}_{1 / 2}$ in comparison to the other sulfonamide complexes [10].

The stability constants of sulfisoxazole complexes are smaller than those of sulfamethaxyzole complexes due to the presence of two $-\mathrm{CH}_{3}$ groups in the former, causing greater steric hindrance [11] in sulfisoxazole complexes than in sulfamethaxyzole complexes. Similar is the position in sulfamethazine and sulfathiazole complexes. In case of sulfacetamide and sulfanilamide, the former is the N1 - acetyl-substituted derivative of sulfanilamide, forming complexes with Mn having lesser stability constants than sulfanilamide complexes. The electron withdrawing group i.e. $-\mathrm{CH}_{3} \mathrm{CO}$ creates much electronic disturbance in sulfacetamide as a result of which its steric hindrance is greater than that of sulfanilamide metal complexes [11]. The highest values of stability constants of sulfanilamide complexes amongst all other sulfonamide complexes are due the maximum shift of $E_{1 / 2}$ in its complexes [10]. The values of stability constants varied from 1.75 to 9.13 , confirming that either sulfonamide or cephalothin or its complexes could be effective against Mn toxicity [12].

\section{Kinetic parameters of [Mn - sulfonamides - cephalothin] system}

The values of kinetic parameters viz. transfer coefficient $(\alpha)$, degree of irreversibility $(\lambda)$ and rate constant $(\mathrm{k})$ of [Mn - sulfonamides - cephalothin] system were determined by Tamamushi and Tanaka methods [13-14] by plotting ( $\left.\mathrm{E}_{1 / 2}{ }^{\mathrm{r}} \mathrm{E}\right)$ against $\log (\mathrm{Z}-1)$, and the plots between $\left(\mathrm{E}_{1 / 2}{ }^{\mathrm{r}}-\mathrm{E}\right)$ vs. $\log (\mathrm{Z}-1)$ are given in Fig. 4. Values of kinetic parameters for the [Mn - sulfadiazine - cephalothin] system are given in Table 3.

Table 3. Kinetic parameters of [Mn-sulfadiazine-cephalotin] system, $\left[\mathrm{Mn}^{2+}\right]=0.05$ $\mathrm{mM}, \mu=1.0 \mathrm{M} \mathrm{NaClO}_{4}, \mathrm{pH}=7.3 \pm 0.01$, temperature $=25^{\circ} \mathrm{C}$.

\begin{tabular}{|c|c|c|c|c|c|}
\hline \multicolumn{7}{|c|}{$[$ Cephalothin $]=0.025 \mathrm{M}$} \\
\hline $\begin{array}{c}{[\text { Sulfadiazine }]} \\
\times 10^{3} / \mathrm{M}\end{array}$ & $\begin{array}{c}\left(\mathrm{E}_{1 / 2}\right)^{\mathrm{qr}} \\
-\mathrm{V} \text { vs. SCE }\end{array}$ & $\alpha$ & $\begin{array}{c}\lambda \\
\mathrm{s}^{-1 / 2}\end{array}$ & $\begin{array}{c}\mathrm{D}^{1 / 2} \times 10^{3} \\
\left(\mathrm{~cm}^{2} \mathrm{~s}^{-1}\right)\end{array}$ & $\mathrm{k} \times 10^{3}\left(\mathrm{~cm} \mathrm{~s}^{-1}\right)$ \\
\hline 0.00 & 1.41 & 0.42 & 2.02 & 3.82 & 7.72 \\
\hline 0.50 & 1.42 & 0.57 & 1.52 & 3.82 & 5.79 \\
\hline 1.00 & 1.43 & 0.46 & 1.52 & 3.82 & 5.79 \\
\hline 2.00 & 1.43 & 0.43 & 1.52 & 3.76 & 5.69 \\
\hline 3.00 & 1.44 & 0.49 & 1.21 & 3.76 & 4.53 \\
\hline 4.00 & 1.46 & 0.54 & 1.52 & 3.69 & 5.60 \\
\hline 5.00 & 1.46 & 0.52 & 1.07 & 3.69 & 3.96 \\
\hline 6.00 & 1.47 & 0.52 & 1.52 & 3.62 & 5.50 \\
\hline 8.00 & 1.47 & 0.57 & 1.21 & 3.56 & 4.31 \\
\hline 10.00 & 1.48 & 0.46 & 1.52 & 3.56 & 5.41 \\
\hline 20.00 & 1.49 & 0.43 & 2.40 & 3.56 & 8.56 \\
\hline 30.00 & 1.50 & 0.44 & 1.52 & 3.49 & 5.30 \\
\hline
\end{tabular}



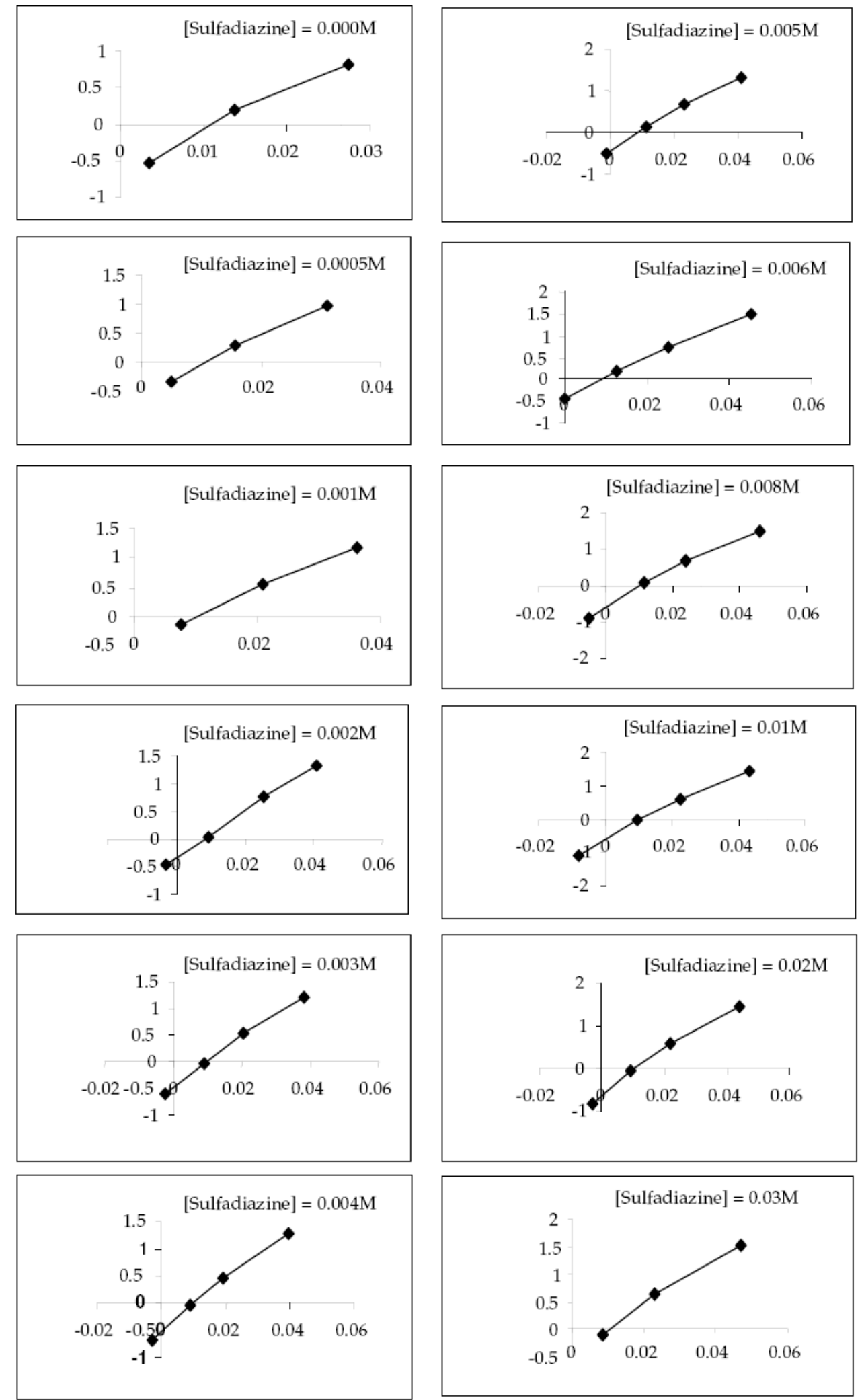

Figure 4. $[\mathrm{Mn}$ - sulfadiazine - cephalothin] system, [cephalothin $]=0.025 \mathrm{M} . \mathrm{X}=\left[\mathrm{E}_{1 / 2}{ }^{\mathrm{r}}\right.$ $\mathrm{E}]$ and $\mathrm{Y}=\log (\mathrm{Z}-1)$.

Values of transfer coefficient $(\alpha)$ varied from $\{0.41$ to 0.59$\}(0.50)$ showing that the 'transition state' behaves between oxidant and reductant response to applied 
potential and it lies in the mid of dropping mercury electrode and the solution interface [15]. The values of diffusion coefficient (D) and degree of irreversibility are as expected [14]. In case of cephalothin, $N$ of the $\beta$ - lactam ring and $\mathrm{O}$ of the carboxylic group took part in bond formation with Mn making five membered rings [16]. The values of rate constant $(\mathrm{k})$ varied from $\left(3.61 \times 10^{-3}\right.$ to $9.93 \times 10^{-3} \mathrm{~cm} \cdot \mathrm{sec}^{-1}$ ) confirming the quasi reversible nature of electrode processes.

\section{Acknowledgements}

The authors are thankful to head, Department of Chemistry, Dr. H.S. Gour University, Sagar, for providing the laboratory facilities and M. P. Council of Science and Technology, Bhopal for enabling the Junior Research Fellowship to M. S. Parihar.

\section{References}

1. S. Bellu and M. Rizzotto, Quim. Nova 30(5) (2007) 1136.

2. L. S. Goodman and Gilman's, The Pharmacological Basis of Therapeutics, $11^{\text {th }}$ ed., The McGraw-Hill Co., New York, 2006.

3. F. Martinez, C.M. Avila and A. Gomez, J. Braz. Chem. Soc. 14(5) (2003) 803.

4. A. Cleasby, A. Wonacott, T. Skarzynski, R.E. Hubbard, G.J. Davies, A.E. Proudfoot, A.E. Bernard, M.A. Payton, T.N. Well, Nature Struct. Biol. 3 (1996) 470.

5. A. Mastrolorenzo and C.T. Supuran, Metal Based Drug 7 (2000) 49.

6. L. Meites, Polarographic Technique, $2^{\text {nd }}$ ed., Interscience Publishers, New York, 1965, p. 62.

7. P.J. Gellings, Z. Elektrochem. 66 (1962) 477; Ber. Bun. Physik. Chem. 67 (1963) 799.

8. D. Deford and D.N. Hume, J. Am. Chem. Soc. 73 (1951) 5321.

9. W.B. Schaap and D. L. McMaster, J. Am. Chem. Soc. 83 (1961) 4699.

10. R.C. Kapoor, B.S. Aggarwal, Principles of Polarography, $1^{\text {st }}$ ed., Wiley Eastern Limited, New Delhi, 1991, p. 40.

11. A.E. Martell, Chemistry of Metal Chelate Compounds, $2^{\text {nd }}$ ed., Prentice Hall Inc., America, 1953, p. 134.

12. F. Khan, J. Chin. Chem. Soc. 52 (2005) 569.

13. R. Tamamushi and N.Z. Tanaka, Phys. Chem. New Folge 39 (1963) 117.

14. R. Tamamushi, K. Ishibashi and N.Z. Tanaka, Phys. Chem. New Folge 35 (1962) 211.

15. P.W. Atkins, Physical Chemistry, W.H. Freeman and Co., San Francisco, 1978, p. 959.

16. F. Khan, J. Chin. Chem. Soc. 54 (2007) 673. 